\title{
Screening antibiotics: industrial research by CEPA and Merck in the 1950s
}

\author{
María Jesús Santesmases (*) \\ $\left(^{*}\right)$ Instituto de Filosofía - Centro de Ciencias Humanas y Sociales, CSIC, Madrid \\ mariaj.santesmases@cchs.csic.es
}

Dynamis

[0211-9536] 2011; 31 (2): 407-427
Fecha de recepción: 30 de diciembre de 2010

Fecha de aceptación: 3 de febrero de 2011

SUMMARY: 1. - Introduction. 2.-The factory system and industrialised research. 3.-Selman Waksman's research agenda. 4.- Industrial connection. 5.- Setting tasks for «screening". 6.-Screening research patterns. 7.- Research in the factory. 8. -At work. 9.-Concluding remarks.

ABSTRACT: This article is an account of a screening programme in search of new antibiotics established by CEPA (Compañia Española de Penicilinas y Antibióticos) and Merck in Madrid in 1954. An exploration of the genealogy for such a programme, its narratives and practices, shows that the main inspiration for this programme was the factory system of production, on the one hand, and Selman Waksman's research agenda on microorganisms of the soil, on the other. In this article, the relationship between industrial production of antibiotics and the research program aimed at identifying new candidate drugs is examined. I suggest that this screening program in search of new antibiotics was organised like industrial manufacturing. The research objects and tools came, both materially and conceptually, from industrial production: a line of artisanship put together in order to obtain a product with the collaboration of every member of the production line. Following the style developed by Selman Waksman in Rutgers, the screening program evaluated samples manually, and the microbiological skills were enhanced with every test. The Madrid team's practice of applying instructions for use led to circulation of knowledge and practices, including research material and microbiological methods.

KEY WORDS: Antibiotic screening, CEPA, Spain, factory system and research, Antonio Gallego, Selman Waksman.

PALABRAS CLAVE: Screening de antibióticos, CEPA, España, sistema fabril e investigación, Antonio Gallego, Selman Waksman. 


\section{Introduction $\left(^{*}\right)$}

Drugs standards, the norms and values of their wonders, belonged and may still belong to an idea of creation and invention closely related to the way of production shown in Modern Times (Charles Chaplin, 1936). Just as industrial production was done on the assembly-line, interconnections of related mechanisms generated products, health standards, ways of inventing and styles of looking at nature. Meanwhile, the production of drugs led to a systematic way of searching for them. This systematization created standards which circulated from one place to another. This was the case when a program to search for new antibiotics was set up in Madrid in the early 1950 s.

It was during the 1950s when Spain began to recover from the devastating effects of the civil war and of the early decade of Franco's dictatorship, during which hunger and poverty combined with corruption and the black market of basic products - bread and drugs among them-during the isolation from abroad ${ }^{1}$. This isolation was double as it was composed of: Franco dictatorship autarchy as a policy for promoting national production and by the policy of the allies toward the dictatorship, which prevented Spanish membership in the international organizations that emerged right after the Second World War².

The Spanish firm created to manufacture penicillin, CEPA, was a combination of firms which were dedicated to production of chemicals, an industrial bank, Banco Urquijo, and Merck (Rahway), which signed an agreement to collaborate in building the factory and in the manufacturing

$\left(^{*}\right)$ The research for this article was funded by the Spanish ministry of Science and Innovation (FFI2009-07522) and benefited of the ESF Research networking program DRUGS by presenting it in one of its workshops.

1. Del Cura, Isabel; Huertas, Rafael. Alimentación y enfermedad en tiempos de hambre: España, 1937-1947. Madrid: Consejo Superior de Investigaciones Científicas; 2007. Cazorla, Antonio. Las políticas de la victoria: la consolidación del Nuevo Estado franquista (1938-1953). Madrid: Marcial Pons; 2000. Catalán, Jordi. La economía española y la segunda guerra mundial. Barcelona: Ariel; 1995. Camprubí, Lino. One grain, one nation: rice genetics and the corporate state in early Francoist Spain (1939-1952). Historical Studies in the Natural Sciences. 2010; 40: 499-531.

2. Portero, Florentino. Franco aislado. La cuestión española (1945-1950). Madrid: Aguilar; 1989. Guirao, Fernando. Spain and the reconstruction of Western Europe, 1945-57. Londres: MacMillan; 1998. 
process of penicillin in $1948^{3}$. Industrial policy of the Franco dictatorship established a tax on the benefits of every industrial firm in the 1940s, which in the case of the iron, steel and concrete industry was between 0.5 and 1 percent of sales. In other cases, the contribution was considered a donation, although it was in fact a hidden tax. Those funds were dedicated to socalled applied research, some of them invested in useless projects, others promoting research in organic chemistry, for example. Those taxes became some of the main funding for applied research at the Consejo Superior de Investigaciones Científicas (CSIC), the research institution created by Franco right after the Civil War ${ }^{4}$. In spite of the arbitrary power of dictatorship authority and nepotism practices, some negotiation became possible for those close to the decision-making process in Madrid. Thus, instead of donating a percentage of its benefits, CEPA created a research centre at the University of Madrid Faculty of Medicine, the Instituto de Farmacología Española (IFE), initially dedicated to physiology, the discipline in which the director of CEPA, Antonio Gallego, was a professor. Gallego's interest in research was wider, however, and became the origin of a negotiation with Merck, after the building of the penicillin factory, which led to a new program in search of new antibiotics which ran from 1954 onwards ${ }^{5}$.

Norms and policies of the Franco dictatorship combined with foreign industrial relationships to provide means and grounds for experimental research ${ }^{6}$. In the case of the program whose creation is explored here, the

3. On penicillin production in Spain and the features of the dictatorship, see Santesmases, María Jesús. Delivering penicillin: the clinic, the hero and industrial production in Spain, 1943-1952. In: Quirke, Vivian; Slinn, Judy, eds. Perspectives on twentieth century pharmaceuticals. Oxford: Peter Lang; 2010, p. 91-117. On history of the pharmaceutical industry in Spain see also Puig, Nuria. Networks of innovation or networks of opportunity? The making of the Spanish antibiotics industry. Ambix. 2004; 51: 167-185.

4. López García, Santiago. El saber tecnológico en la política industrial del primer franquismo [doctoral thesis]. Universidad Complutense; 1994. López García, Santiago. La investigación científica y técnica antes y después de la guerra civil. In: Gómez Mendoza, Antonio, ed. Economía y sociedad en la España moderna y contemporánea. Madrid: Síntesis; 1996.

5. Santesmases, María Jesús. Entre Cajal y Ochoa: ciencias biomédicas en la España contemporánea. Madrid: CSIC; 2001, chapter 4.

6. I have explored elsewhere research activity in Spain as a combination of national policies and foreign collaboration and influence. See for example Santesmases, María Jesús. Severo Ochoa and the biomedical sciences in Spain under Franco, 1959-1975. Isis. 2000; 91: 706-734, and Santesmases, María Jesús. Orígenes internacionales de la política científica. In: Romero, Ana; Santesmases, María Jesús, eds. Cien años de política científica en España. Madrid: Fundación Banco Exterior; 2008, p. 293-327. 
interest of CEPA to have a research activity at the Spanish firm which was manufacturing penicillin appears to have coincided with the interest of Merck in diversifying its research activities while also keeping active its line of research for new antibiotics started by Selman Waksman.

This article is an account of a screening programme in search of new antibiotics established by Merck (Rahway) and CEPA (Compañía Española de Penicilinas y Antibióticos - Madrid) in 1954. An exploration of the genealogy for such a programme, its narratives and practices, shows that the main inspiration for this programme was the factory system of production, on the one hand, and Selman Waksman's research agenda on microorganisms of the soil, on the other.

In this article, the relationship between industrial production of antibiotics and the research program aimed at identifying new candidate drugs is examined. I suggest that the screening program in search of new antibiotics was organised industrially. Research was motivated and organised according to industrial management. This case could be described as a counter-linear model. That is, it shows the origins of research in the factory instead of the opposite, which would have been building the factory after some research was carried out ${ }^{7}$.

The research program analysed here included training, personal instructions and repeated manipulations while keeping laboratory skills at the core of work place practices. Instead of being like the invisible industrialists analyzed by Ilana Löwy and Jean-Paul Gaudillière, the researchers of CEPA were visible. They were as visible as the factory in which they worked, developed a research project and assembled a line of production of samples whose antimicrobial activity would be detected. Research objects and tools of this screening program in search of antibiotics came, both materially and conceptually, from industrial manufacturing ${ }^{8}$. And it was in the factory where the research program and the materials and research participants

7. On the linear model, from research to industrial production, see the contributions to Part I in Grandin, Karl, Nina Wormbs, Sven Widmalm, eds. The science-industry nexus. History, policy, implications. Sagamore Beach: Science History Publication; 2004. See also in Hulverscheidt, Marion A. The scientific entrepreneur or financing in pharmaceutical research. A portrait of the mariologist Werner Schulemann, 1888-1975. In: Quirke; Slinn, n. 3, 121-148. This is an account of research done at a research laboratory by a scientist who had started his career at an industrial laboratory.

8. See the contributions to Löwy, Ilana; Gaudillière, Jean-Paul, eds. Invisible industrialist. Manufactures and the production of scientific knowledge. London: MacMillan Press; 1998. 
occupied physical space. The research was part of the factory itself and followed industrial patterns of action. So it was not only that devices used had been manufactured by an industrial firm and became part of the work at the bench; it was that the design of the research program itself was a product of an industrial project, that of producing antibiotics in Spain.

Samples screening was the practice at Selman Waksman laboratory at Rutgers University. The routine of repeated manipulation of soil samples in search of new Actinomycetes was far from being the «uncreative testing techniques» Kingston talks about ${ }^{9}$. Samples were evaluated manually, and the microbiological skills were enhanced with every test. By applying instructions for use, by following recipes elaborated somewhere else, the Madrid team's work was a product of the circulation of knowledge and practices. It showed training and knowledge production in microbiology and industrial manufacturing style through the circulation of research material and methods of microbiology.

\section{The factory system and industrialised research}

In studying this screening programme, two features should be stressed. One is the fact that a research initiative was set up right after the creation of a factory for penicillin manufacturing in Madrid ${ }^{10}$. This special case of research emerging from a factory gave the screening program the same characteristics as a factory system. The research for new antibiotics was an assembly line of tasks done under supervision. And it was indeed part of a process of industrialisation, which at that particular time in Madrid meant building factories to make products in Spain whose production process was patented abroad. That is, manufacturing procedures were brought from a U.S. firm to a Spanish firm ${ }^{11}$.

9. Kingston, William. Streptomycin, Schatz v. Waksman, and the balance of credit for discovery. Journal of the History of Medicine and Allied Sciences. 2004; 59: 441-462, where it is stressed the repetitive nature of Waksman's screening so as to reinforce Waksman's authority and thus wresting authority from collaborators of him like Albert Schatz, with whom priority conflicts arose regarding streptomycin. On this see also Wainwright, Milton. Streptomycin: discovery and resultant controversy. History and Philosophy of the Life Sciences. 1991; 13: 97-124.

10. Santesmases, n. 4.

11. On technology transfer from abroad into Spain see Cebrián, Mar. Technological imitation and economic growth during the Golden Age in Spain: 1959-1973 [doctoral Thesis] Florence: 
Previous pharmaceuticals produced in Spain were vaccines and sera, both made during the first third of the 20th century at the Instituto de Higiene created and funded by the State, and in private firms. The chemical industry was dependent on supplies bought abroad: dyestuffs and fertilizers were also bought abroad for the textile industry ${ }^{12}$. Thus, the trajectory of Ehrlich in the pharmaceutical industry, which led to salvarsan, prontosil and sulfa drugs from dyes, was an exception that helps to explain the developments of the German pharmaceutical industry coming from the chemical industry ${ }^{13}$. The case presented here shows a path from industry to research; research was a result of industrial production, a product of industrialisation. The research area was microbiology, that is, expertise in handling and isolating microbes and their prospective antagonists.

Training in microbiology and culturing techniques took place during the process of creating and setting up a screening program for new antibiotics ${ }^{14}$. Doing research in microbes screening in search of new antibiotics was in tune with the rhetoric of the time, which put research as the path toward economic recovery and industrial development that was predominant in the West from post-Second World War and throughout the Cold War ${ }^{15}$.

European University Institute; 2004. Also López, Santiago; Cebrián, Mar. Economic growth, technology transfer, and convergence in Spain, 1960-1973. In: Ljunberg, Jonas; Smits, JanPieter, eds. Technology and human capital in historical perspective. New York: PalgraveMacmillan; 2004, p. 120-144. On the factory system of production from the point of view of the history of economics and industry see Chapman, Stanley D. The textile factory before Arkwright: a typology of factory development. Business History Review. 1974; 48: 451-478. Carlsson, Bo. The development and use of machine tools in historical perspective. Journal of Economic Behaviour and Organisation. 1984; 5: 91-114. Mokyr, Joel. The rise and fall of the factory system: technology, firms and households since the industrial revolution. CarnegieRochester Conference series on Public Policy. 2001; 55: 1-45. Geraghty. The factory system in the British industrial revolution: A complementarity thesis. European Economic Review. 2007; 51: 1329-1350.

12. Puig, Nuria. El crecimiento asistido de la industria química en España: Fabricación nacional de colorantes y explosivos, 1922-1965. Revista de Historia Industrial. 1999; 15: 105-136. And also Puig, Nuria; Loscertales, Javier. Las estrategias de crecimiento de la industria química alemana en España, 1880-1936: exportación e inversión directa. Revista de Historia Económica. 2001; 19: 345-382.

13. Lesch, John. The first miracle drugs. How sulfa-drugs transformed medicine. Oxford-New York: Oxford University Press; 2007.

14. On culturing techniques of human tissues, see Landecker, Hanna. Culturing life: how cells became technologies. Cambridge, MA: Harvard University Press; 2007.

15. OECD 1961; and Santesmases 2008, n. 6. 
It was also the era of screening, of systematically testing cultures, samples and techniques in order to find better ways for diagnosis and treatments ${ }^{16}$. It was a time of great hope regarding a world without infections. There was an interaction between industrialisation, as a way of distributing work along an assembly line, and that of screening as a testing assembly line, of systematically looking for antimicrobial activity in samples from which an antibiotic could be detected and isolated. It was as if the way of screening, as such, was modelled on industrial organisation. Not only was there a sequence of tasks, but also an integrated set of procedures aimed at mass-producing new samples of antibiotics. Both means - a production line - and aims - mass-production- permits characterizing the screening program in search of new antibiotics as a factory system ${ }^{17}$.

In the case presented here, screening was understood as a lineal way of making tests, getting evidence and finding proof, either of the presence or the absence of something. In this sense, John Lesch's book, The First Miracle Drug, is suggestive, and convincing, regarding the instrumental role played by research on sulfa drugs development, as it created a culture of systematically testing reagents which might add a functional group to a molecule whose therapeutic effect could increase while decreasing its toxicity. Although not called screening, it was a system of production of prospective new anti-infective chemical products.

Microbes cultures, however, were different. Their handling required particular skills and different sensitivity. And they did not have the technical requirements that organic and biological chemistry of dyestuffs and sulfa derivatives had ${ }^{18}$. Activity was what was identified instead of structure, or any further chemical characterisation such as chemical composition and prospective chemical synthesis. Even if systematised, microbiological practices of screening evoked artisanal work: careful looking at microbe cultures, at the rings around them, their shape and intensity. Chemical identification,

16. See the screening of viral particles for the treatment of human cancer in the 1950s in Gaudillière, Jean-Paul. Circulating mice and viruses: The Jackson Memorial Laboratory, The Cancer Institute and the genetics of Breast Cancer, 1930-1965. In: Fortun, Michael; Mendelsohn, Everett, eds. The practices of human genetics. Dordrecht-Biston: Kluwer; 1999. On the screening of cervical cancer, see Löwy, llana. Preventive strikes. Women, precancer and prophylactic surgery. Boston: Johns Hopkins University Press; 2010.

17. On the factory system in historical perspective see n. 11.

18. Bud, Robert. The uses of life. Cambridge: Cambridge University Press; 1993. On fermentation in history of antibiotics see Bud, this volume. 
on the other hand, evokes post-industrial technology as it was mediated by a diversity of devices. Screening as a term was indeed used for those techniques of searching for antagonists of microbes.

In the screening program set up jointly by Merck and CEPA in Madrid, the tasks of the CEPA laboratory were basically microbiological. It included collecting soil samples and the isolation of microbes whose antibiotic capacity would be tested against a list of known bacteria. The preparation of concentrated samples of the antimicrobial and its toxicity characterisation would be the aim of the research work in Madrid. Further chemical identification of the active product in the extract would be done at Merck Research Laboratories in Rahway (New Jersey).

The identification of antibiotic capacity of the sample and the characterisation of microbes of the species Actinomycetes included careful handling of Petri dishes and looking at the ring which might surround an active sample. Merck, meanwhile, concentrated on the more highly-technical skills of chemical isolation and identification of composition and structure, and on the synthesis needed for this as well. Even if microbiology came to replace chemistry as the discipline involved in finding new antibiotics from penicillin onwards, chemistry remained a remarkable area of expertise in drugs research and production.

\section{Selman Waksman's research agenda}

Soil microbiology was Waksman's early research project as a graduate student, the subject by which many of his students were introduced to research, and the platform from which systematic research on the antagonistic action of soil microbes took place. This eventually led to the finding of streptomycin at Rutgers, in a collaborative project with Merck (Rahway) ${ }^{19}$.

The collaboration between Merck and Waksman started in 1938 when Merck hired Waksman as a consultant and established a fellowship in fermentation studies at Waksman's laboratory ${ }^{20}$. Together with Woodruff, they found an antibiotic from Actinomycetes which proved to be highly toxic

19. Accounts of these events are in Wainwright n. 9, and Kingston n. 9.

20. Lechevalier, Hubert. The search of antibiotics at Rutgers University. In: Parascandola, John, ed. The history of antibiotics. A symposium. Madison: American Institute of the History of Pharmacy; 1980, p. 113-123 
to experimental animals. As a result, according to Waksman's recollections, a «comprehensive programme of screening Actinomycetes» ensued, as they had noticed that there was a diversity of antibiotics to be found among Actinomycetes in terms of antimicrobial activity, chemical features and toxicity to animals. As penicillin left the gram-negative bacteria «gap», the main challenge was to obtain antagonists of those bacteria ${ }^{21}$.

These biological products were everywhere in Waksman's research landscape. Actinomycetes were the microorganism that Waksman knew best. By the 1910s, Waksman with R. E. Curtis had obtained «hundreds» of Actinomycetes from soils. They were «fascinated» by their structure and function and, once they had been characterised, they established the bases for regarding such microorganisms as ones that limited bacterial growth in soil through what was called their «antagonistic nature», the capacity of one microorganism to kill others, an idea that is at the very heart of bacteriology $y^{22}$. By then, Waksman was a lecturer on soil bacteriology at Rutgers Agricultural College, and his research agenda revolved around what could be called soil ecology; that is, the study of the relationship between different types of microorganisms in the soil ${ }^{23}$.

\section{Industrial connection}

The relationship between Merck and Selman Waksman's laboratory developed over the years. Some former Waksman students were hired by Merck's research laboratories, whose facilities were available for any development the Rutgers group might make at the University ${ }^{24}$. The earliest patenting results were those of Waksman and Schatz on streptomycin in 1943, which turned out to be active against «certain forms» of tuberculosis and

21. Waksman, Selman. Streptomycin: background, isolation, properties, and utilization. Nobel Lecture, Dec 12, 1952, p. 370-388.

At http://nobelprize.org/nobel_prizes/medicine/laureates/1952/waksman-lecture.pdf .

22. Woodruff, H. Boyd. Selman Waksman. Historical background. Annals of the New York Academy of Sciences. 1960; 89: 287-298.

23. Sakula, Alex. Selman Waksman 1888-1973, discoverer of streptomycin: a centenary review. British Journal of Disease of the Chest. 1988; 82: 23-31.

24. Galambos Louis. Values \& visions: A Merck century. Rahway: Merck and Co; 1991, p. 74. 
Hemophilus among others, and of Waksman and Harold Boyd Woodruff on actinomycin ${ }^{25}$.

By then, and on the basis of an agreement with Rutgers, Merck held patent rights for the production of all substances identified and isolated in the framework of this agreement, and of some others as well (whereby research funds from Merck were granted to Waksman's laboratory to search for new antibiotics). Later on, Waksman renegotiated the agreement: Rutgers obtained patent rights on both antibiotics, streptomycin and actinomycin, and Merck accepted a non-exclusive license to produce streptomycin ${ }^{26}$.

After taking part in the war effort for the efficient production of penicillin, Merck (Rahway) became the owner of patent rights to produce penicillin and streptomycin and started to license them outside the U.S. This was the arena for Merck's relationship with Spain at that time. Through a commercial agreement signed in 1948, a new firm was set up by a group of Spanish chemical and pharmaceutical companies which belonged to Banco Urquijo (a Spanish merchant bank) after entering into a contract with Merck (Rahway) to build a penicillin production plant in Madrid ${ }^{27}$.

At that time, the research group led by Waksman at Rutgers University had successfully developed «a comprehensive programme of screening Actynomicetes for their ability to produce different antibiotics», a programme envisaged after reading the early papers on the antibacterial activity of penicillin extracts ${ }^{28}$. They obtained collections of soil samples, plated them out, isolated Actinomycetes and tested them for antibiotic activity against non-pathogenic strains of mycobacteria over and over again in the hope of finding new substances active against pathogenic strains ${ }^{29}$. This seemingly simple project, whose description may evoke routine and repetitive activity, was dutifully maintained at Waksman's laboratories even in the 1950s, when a perception spread that no new antibiotics were

25. For a list of diseases responding to streptomycin see Waksman, n. 21, p. 383-384. The activity of streptomycin in the treatment of penicillin was widely celebrated at its time. See Comroe, Julius H. Pay dirt: the story of streptomycin part II. Feldman and Hinshaw; Lehmann. American Review of Respiratory Disease. 1978; 117: 957-968.

26. Lechevalier, n. 20.

27. Santesmases, n. 3. Copies of the agreements are at the Archivo General de la Administración, Industria, Alcalá de Henares, Madrid.

28. Woodruff, H. Boyd. Natural products from microorganism. Science. 1980; 208: 1225-1229.

29. Waksman, n. 21. 
needed, taking into account the number of them already being isolated, identified and manufactured ${ }^{30}$.

However, the increasing resistance of bacteria to the activity of many antibiotics spurred on the search for new ones. The systematic research on soil preparations as a repetitive, planned programme was part of a microbiological strategy, closely associated to the meaning of «antibiotic» as a term coined by Waksman himself ${ }^{31}$. According to his own narrative, this research program began to yield time and again the same antibiotics that were already known, as the same one could be produced by different species $^{32}$. «At this point, a more creative research approach to screening becomes essential» ${ }^{33}$.

Previous commercial agreements between Merck and CEPA were managed by the director of CEPA, Antonio Gallego. The Spanish market, the Spanish public, and Franco's dictatorship were more than a mere context for the dissemination of therapeutic success of penicillin and its industrial manufacturing in Spain. During the second decade of Franco's dictatorship, penicillin functioned as a heroic medical and scientific object as well as a State-controlled product. It saved lives but was also embedded in the regime's bureaucracy ${ }^{34}$.

Once the penicillin factory in Madrid was manufacturing the drug, Gallego suggested «a new research endeavour» at CEPA's laboratories using fees from penicillin and streptomycin manufacturing licences ${ }^{35}$. The documents on the agreement, as well as testimonies provided by his former collaborators at CEPA, suggest that Gallego was fully aware of the research programme developed by the Merck Research Laboratory and

30. In 1952, forty-four antibiotics were listed by Spector, William, ed. Handbook of biological data. Philadelphia-London: W.S. Saunders Co.; 1952. Se also Lechevalier, n. 20.

31. Waksman, Selman. What is an antibiotic or antibiotic substance? Mycologia. 1947; 39: 565569. On antibiotic as a brand, see Bud, Robert. From Germfobia to carefree life and back again. The lifecycle of the antibiotic brand. In: Tone, Andrea; Watkins, Elizabeth Siegel, eds. Medicating modern America: prescription drugs in history. New York: New York University Press; 2007, p. 17-41.

32. Waksman, n. 21.

33. Woodruff, H. Boyd; Hernández, Sebastián; Stapley Edward O. Evolution of an antibiotic screening programme. A tribute to Justo Martínez Mata. Hindustan Antibiotics Bulletin. 1979; 21: 71-84.

34. Santesmases, n. 3.

35. Strohl, W. R.; Woodruff, H. B.; Monaghan, R. L. et al. The history of natural products research at Merck \& Co., Inc. SIM News. 2001; 51: 5-19. 
Merck Institute for Therapeutic Research, set up in $1938^{36}$. From his early contact with Merck in 1947 as the representative of the Spanish bank which had signed the agreement for manufacturing penicillin in Spain, Gallego's relationship with Merck successfully developed.

The research collaboration also came about, at least in part, to fulfil the requirements of the State concession to Banco Urquijo for producing penicillin in Spain: the firm was required by the concession decree to conduct research on Spanish sources for antibiotics ${ }^{37}$. Research facilities were built in one of the factories. Scientific personnel from CEPA recall that part of the quality control department was used for that purpose.

By the time of the signing of the agreement, in September 1954, a streptomycin production plant was working all-out. Waksman came to Madrid for the inauguration on the tenth anniversary of the «discovery» of the drug, according to the 1954 CEPA annual report ${ }^{38}$.

\section{Setting tasks for «screening»}

The contract signed in 1954 stated that CEPA wished to set up an antibiotic screening programme aimed at the discovery and development of antibiotics ${ }^{39}$. What screening meant at that exact point was not clear to the young microbiologist who applied for a post in the CEPA laboratory, Sagrario Mochales ${ }^{40}$. It appears to have been used by Merck and CEPA for this particular project aimed at systematically testing soil samples in search of Actinomycetes possessing antibiotic activity. The programme consisted of a search for new antibiotics active against gram-negative bacteria. At that time Merck was interested in broadening the search for new antibiotics «but

36. Swann, John P. Academic scientists and the pharmaceutical industry: cooperative research in twentieth-century America. Baltimore: Johns Hopkins University Press; 1988.

37. Boletín Oficial del Estado [Official State Gazette] 11 Aug 1949, decree dated 17 June.

38. Fondos Servicio de Estudios del Banco Urquijo, Instituto Juan March de Investigaciones Sociales Avanzadas, Madrid. I would like to thank Antonio Gómez Mendoza for his advice in consulting this archive.

39. Agreement made and entered into as of the 14th of January 1949 between Merck \& Co., Inc and Banco Urquijo. Contracts 37QC, boxes 5112 and 5113, IDD 1.04. Ministerio de Industria. Sección de Subsecretaría (Asistencia Técnica), Archivo General de la Administración (AGA), Alcalá de Henares, Madrid (in English in the original). I would like to thank Mar Cebrián for her guidance in consulting these files at the AGA.

40. Mochales interview 1994. 
the cost of doing so and the interference with ongoing research projects, were inhibitory» ${ }^{41}$. An opportunity arose when Antonio Gallego suggested a collaborative research project. H. Boyd Woodruff was head of the research section and later director of the department of microbiology and natural products isolation at Merck in Rahway. Woodruff had trained with Selman Waksman at Rutgers, with whom he published papers on microorganisms isolated from the soil during the 1940s, before being hired by Merck.

According to remembrances of Gallego's collaborators, it was at Gallego's initiative that the research program was established in Madrid. Apparently, for Merck it was an opportunity to initiate new research in Rahway, including the program to develop drugs to destroy the microbial plaque attached to teeth and the one to explore the antigenic properties of bacterial polysaccharides ${ }^{42}$.

The purpose of the cooperative project established between CEPA and Merck was to look for new soil samples, samples from other soils, collected everywhere «by Merck sales agents» and sent to Madrid to be tested for their antagonist activity. CEPA's scientific director, Antonio Gallego, was involved early on in Madrid and, with Randolph T. Major from Merck Research Laboratories, formalised the cooperation agreement. Lloyd F. McDaniel (Merck) and Justo M. Mata (CEPA) were appointed as directors of the programme ${ }^{43}$.

In order to search for new antibiotics in new soils, the Spanish group had to learn the culturing techniques, the method of treatment of the samples and ways of testing them. CEPA medical researcher Sebastián Hernández went to the Merck Research Laboratories in Rahway to be trained in the programme's laboratory practices. Laboratory equipment, reagents and methods for isolating and testing the soil extracts were «transferred» from Rahway to Madrid, and McDaniel and Woodruff travelled there frequently, particularly during the period when the laboratory and the screening line were being assembled. An exchange of visits took place during the early stages of the programme until it was completely set up according to Merck standards ${ }^{44}$.

\footnotetext{
41. Strohl et al., n. 35, p. 9.

42. Woodruff, n. 28.

43. Strohl et al, n. 35.

44. Mochales interview. See also Mochales, Sagrario. Ten years of CIBE symposia, 1989-1998. International Microbiology. 1998; 1: 251-254.
} 
By 1956, the activity of the programme at the CEPA research laboratory in Madrid included: isolation of Actinomycetes, testing the isolates against a set of bacterial products, development of active cultures in shake flasks, resistance test of broths and determination of antibacterial spectrum, further production in 5-litre flasks and confirmation of previous identification (if any), preparation of concentrates and toxicity tests, and «determination of protective levels and calculations of therapeutic indices by tests on infected mice». The agreement included details of the facilities needed to carry out the programme: one laboratory for isolation, one for identification, a chemical laboratory and a biological laboratory. Those «four screening laboratories» needed one supervisor, three to four assistants and a dozen technicians. The agreement even laid down the weekly output requirements of the programme: 12 soil samples, 500 tested isolates, 30 cultures in shake flasks, 6 cultures in fermenters and two new products in animal tests ${ }^{45}$. The list of duties included in the agreement suggests that there was to be a reproduction of a pre-existing pattern: that of Waksman and Merck research laboratories working together.

\section{Screening research patterns}

The programme proved to be «highly productive» in terms of figures of soil samples collected, fermented, isolated, concentrated and tested in bacterial cultures and in rats. Fifty thousand new isolates per year were tested ${ }^{46}$. This joint programme relied on biological techniques to identify antimicrobial substances. An «antimicrobial spectrum conducted on gradient plates and cross-resistance studies with mutants of E. coli» proved especially useful ${ }^{47}$.

According to the microbiologists who worked with the group, methods for isolating and testing samples and broths were kept secret ${ }^{48}$. However, in 1958 the group of CEPA researchers published a report in which methods quite similar to those described by Waksman in his Nobel lecture of 1952 were used. The group started to publish the results of the research conducted from 1957 onwards in a Spanish journal (Anales del Instituto de

\footnotetext{
45. Agreement, n. 39.

46. Strohl et al, n. 35.

47. Woodruff; Hernández; Stapley, n. 33, p. 75

48. On secret and penicillin patents see Romero, this issue.
} 
Farmacología Española), and in those papers they gave an account of the methods used and the antibiotic activity found ${ }^{49}$.

The soil sample was suspended in sterile water and an abundance of antagonists using a series of solutions from 1:10 to 1:10.000 were tested. A one millilitre portion of these solutions was placed in a Petri dish and the bacterial agar prepared beforehand for the trial was added. The presence of antagonists was shown by the clear zones formed surrounding the colonies. The following step was to dilute soil samples and culture them in shaking flasks in a procedure similar to the submerged aerated culture that led to efficient yields of penicillin from Penicillium cultures ${ }^{50}$.

To achieve a more concentrated extract of the prospective antibiotic substance the broth was treated with charcoal, which absorbed it, and was later on diluted with acid so as to extract it back. The antimicrobial activity was evaluated by monitoring the activity against a list of gramnegative bacteria. This was the case of the isolation of a xanthomycin in CEPA in $1957^{51}$.

The main difference between the procedures at CEPA and Merck was that at the CEPA laboratories the submerged fermentations, when presenting any antibiotics activity, were tested on mice. Therapeutic activity was studied by intra-peritoneal injection and by later sacrificing the animal to check for toxicity in the organs. Local regulations did not prevent the use of laboratory animals as they did in New Jersey at that time ${ }^{52}$.

\section{Research in the factory}

This modern style of producing new substances, or samples that might contain them, evokes that of early industrial production: the integration of workshops under the same roof, supervised by a person in charge of the

49. Martínez Mata, J.; Hernández, S.; Mochales, S.; Maldonado, F.; Moreno, A.; Gallego, A. Un programa de investigación de nuevos antibióticos II. Aislamiento y caracterización de una xantomicina antibiótico 1561 (4). Anales del Instituto de Farmacología Española. 1958: 267-270.

50. Waksman, Selman; Woodruff, W. Boyd. The soil as a source of microorganisms antagonistic to disease-producing bacteria. Journal of Bacteriology. 1940; 40: 581-600.

51. Hernández, S.; Mochales, S.; Martínez Mata, J.; Gallego, A. Un programa de investigación de nuevos antibióticos. I. Resultados del año 1957. Anales del Instituto de Farmacología Española. 1958: 263-266.

52. Swann, n. 36 . 
whole process. One person took the sample and sent it to the programme site (CEPA, Madrid); a second did the first step, from which came the second and successive steps so that, in the end, something new, active and non-toxic was achieved. It was a process of progressive selection with a pyramidal appearance. The final successful product remained at the top, showing an increasingly important, sensitive procedure in order to obtain an active sample.

The way in which research was done systematically, by a line of tasks, as I said, can be perceived as routine. It also evokes industrial, assemblyline manufacturing of successive artisanal works - no automatic procedures were in use, just a line of manual tasks establishing standard hand-made procedures that could be reproduced elsewhere. Those interactions show a landscape in which research agendas and industrial, manufacturing needs shared both experts and expertise and, what may have been more relevant, these two professional spaces shared interests and modes of production.

The whole project was attuned to other screening programs of the time: PKU (phenylketonuria) screening in newborns as well as cancer viruses screening were started at the same time. Screening evokes, on one hand, war time efforts of systematically searching for solutions to military problems or concerns and, on the other, a legacy of chemistry and of earlier strategies developed in Germany which finally produced sulfa drugs ${ }^{53}$.

At the same time, it was a production line where training was involved: tasks functioned as a means of invention while keeping the activity as part of a pre-design line. The production line was created as part of a factory; it was attuned to the factory system. The factory and the research programme exchanged means of production. Homogenisation was part of a culture that included research-programme ways of working, of assembling a set of tasks in search of new products within the factory space. This work distribution of the research programme and the factory were mutually consistent: they shared an industrial production culture as well as space in the manufacturing plant.

53. On PKU, see Paul, Diane. PKU and procreative liberty: historical and ethical considerations. Philosophy and Medicine. 2002; 65 (part II): 171-190. See also Paul, Diane; Edelson, Paul J. The struggle over metabolic screening. In: De Chadarevian, Soraya; Kamminga, Harmke, eds. Molecularizing biology and medicine. New practices and alliances. Amsterdam: Harwood; 1998, p. 203-220. On screening of cancer viruses, see Löwy; Gaudillière, n 8, and Gaudillière, n. 16. On sulfa drugs, see Lesch, n. 13. 
The soils were a source of microbes as well as a source of their antagonists. This particular practice of the search for new antibiotics was normal at that time: one that specifically integrated the expertise Waksman provided to Merck. CEPA's research laboratory had an artisanal way of working and carefully observing broths, antimicrobial activity and managing the uniqueness of each new sample and each microorganism found ${ }^{54}$. The research space was set within the quality control laboratory and was the result of interaction between different professional cultures.

\section{At work}

By 1957, the CEPA research laboratory was working at full steam. More than 95,000 plates of soil samples had led to isolation and fermentation tests being conducted on 22,000 of them. These samples were contaminated by Neurospora in January and in June. To check their antimicrobial activity, the isolated broths were tested against a select list of germs. They were searching for antibiotics showing activity against bacteria that had been resistant to previously developed antibiotics, mostly Gram-negative bacteria such as Staphilococus aureus. Inactive samples and those active against Gram-positive bacteria were discarded. Thirty percent of the samples were active. Further identification by chromatography led to 126 being discarded, and the 41 left were tested in a third fermentation against E. coli strains. From them, three new neomycine, one xanthomycine and two unknown antibiotics were identified. Those samples, previously concentrated, were sent to Rahway, in whose research laboratories the substances were purified and identified. The small group of researchers enjoyed their work and introduced modifications to improve methods of isolation and identification ${ }^{55}$.

At some point, by the late 1960s, further chemical and microbiological studies on the concentrate were fed into a computer in order to compare them with all the antibiotics already identified. "The machine excludes normally more than 90 per cent of the broths and kept a small residue of them really productive of new antibiotic substances». In other words, the machine accepted very few new products as antibiotics. Most of the samples

\footnotetext{
54. Mochales interview.

55. Hernández; Mochales; Martínez Mata; Gallego, n. 51.
} 
whose characteristics were introduced into the machine were considered by the program to not be new, meaning they had already been characterised ${ }^{56}$. Computerization became the "obvious answer» to the problem of identifying a product as new, at a time when the catalogue of antibiotics was fast increasing in size. From more than 300 listed in 1957, by the late 1970 s the number rose to 2,400. Each antibiotic known was then fed into a computer programme and its properties allowed every new finding to be checked, by comparing its properties with those of the antibiotics stored «in the memory bank». Computer technology in this case involved gathering the known antibiotics and classifying them according to selected properties. Later on, the computer was programmed «as a learning machine» 57 .

By means of this research programme at CEPA, Merck shifted the major screening to Spain and initiated new fields of research in Rahway, such as one on the attack of dental caries ${ }^{58}$.

The screening work based on natural products continued until 2006, when Merck closed what was by then a 50 year-old research centre on natural products. During its history, a set of antibiotics was identified and three of them went onto the market: fosfomycin, cephamycin and thienamycin. Fosfomycin was developed by CEPA in Spain. Cephamycin and thienamycin derivatives were marketed by Merck. Cephamycin $\mathrm{C}$ led to the development of semisynthetic cephalosporin, cefoxitin, widely used in hospitals in the 1980s. Thienamycin derivative was marketed and used to treat bacterial infections in hospitals. Further drugs identified as part of this program at CEPA research laboratory were the statins used to control atherosclerosis and cardiovascular risk. Later on, antifungals were among the type of drugs isolated by what in 1980 became a research centre, CIBE $^{59}$.

56. Martínez Mata, Justo. La investigación de antibióticos en la industria farmacéutica española. Historia de un descubrimiento: la fosfomicina. Química e Industria. 1974; 20: 51-59.

57. Woodruff; Hernández; Stapley, n. 33. On data base' construction and computers, see also García-Sancho, Miguel. From metaphor to practices: the introduction of information engineers into the first RNA sequence database. History and Philosophy of the Life Science. 2011 (in press).

58. Woodruff, H. Boyd. A soil microbiologist's odyssey. Annual Review of Microbiology. 1981; 35: 1-28 (23).

59. Peláez, Fernando. Introduction: 50 years of CIBE. In: CIBE: 50 años de investigación. Madrid: Merck Sharp and Dhome España; 2005, p. 23-33 (p. 24-25). See also Peláez, Fernando. The historical delivery of antibiotics from microbial natural products — can history repeat? Biochemical Pharmacology. 2006; 71: 981-990. 


\section{Concluding remarks}

Research standards circulated from one pharmaceutical company to another, from one country to another, from a microbiological laboratory to a quality-control laboratory, and amongst different professional groups. These standards, emerging in a collaborative research program, included technical and research skills and entrepreneurial relationships that became stabilized. By providing results, concentrates of prospective new antibiotics, the antibiotic screening program generated feedback, that is to say, more circulation. On this journey, and by crossing national, professional and local boundaries, drugs research led to collaboration and the development of skills.

In the case presented here, it was a research project that travelled and, more broadly, a research agenda which formed part of the biography of a firm whose previous and current main function was to manufacture antibiotics; that is, to build up an antibiotics factory and keep it functioning. Screening was, as I suggest, attached to the factory system and was a result of the interactions between two spaces, professional and social. Through these spaces, tasks and knowledge circulated and created an intersection, the arena in which the particularities of an antibiotic screening program developed.

This is a particular case of research done by an industrial firm, a very unusual task to be carried out by a firm in Spain in the early 1950s. By the end of the first decade of the Franco dictatorship, contracts for industrial production were starting to be bought by Spanish entrepreneurs, companies and even dictatorship authorities so as to participate in the international industrial development that showed promise at that time. Turn-key contracts to build-up factories and to manufacture a wide variety of products were bought, in what can be regarded as a reaction against the previous compulsory autarchy. By the early 1950s, national borders began to be crossed from abroad by many companies eager to get into new markets, while Spanish entrepreneurs, engineers and scientists had also begun to travel abroad for training and to learn about new techniques, especially to the U.S. It was indeed the case of the screening program of antibiotics itself, which can well be regarded as a turn-key research program which contributed to learning and training in a factory, both of the factory workers and the personnel involved in microbiological techniques for industrial purposes. Production of other new antibiotics came at the same time, and by the mid- 
1950s streptomycin was also being made in Spain by CEPA with another Merck patent.

A question remains as to what extent this screening program was contributing to blur the borders that separated industry from research, as both were systems of production. The screening research program at CEPA in collaboration with Merck couldn't be understood without the factory. Even the agreement between CEPA and Merck for the research program can only be understood by recalling that the previous agreement for antibiotic manufacturing in Madrid was already in force and well-developed.

Screening became a way of systematically searching for something, either the absence or the presence of a given product (molecule, enzyme, antibiotic) in a given set of samples (soil, blood, a mixture of whatever origin) ${ }^{60}$. Waksman himself was proud of having had a group of assistants and students who tested more than 10,000 cultures from various natural substrates, ten percent of which showed antibacterial activity, and from them, finally, ten antibiotics were submitted for biological evaluation. This way of working at Rutgers started in the late $1930 \mathrm{~s}^{61}$.

Finally, I would like to suggest that the industrial nature of CEPA's research laboratory and, by extension, of the screening programme, was embedded in, or reverted to, natural history-style collection methods ${ }^{62}$. By systematically and manually collecting so much information about different kinds of cultures, the program integrated not only artisanship in every step, as I suggest above, but also, as microbiological collections do, brought natural

60. For a wide discussion on screening in relation to standards and regulation see Gaudillière, Jean-Paul. The singular fate of industrial screening in twentieth century pharmacy. Some thoughts about drug standardisation and drug regulation. In Bonah, Christian; Masutti, Christophe; Rasmussen, Anne; Simon, Jonathan, eds. Harmonizing drugs: standards in 20thcentury pharmaceutical history. Paris: Glyphe; 2009, p. 153-180.

61. Waksmann, Selman. The antibiotic era: a history of the antibiotics and of their role in the conquest of infectious diseases. 1975, published posthumously, quoted in Comroe J. H., Jr. Pay dirt: the story of streptomycin. I: from Waksman to Waksman. Retrospectroscope. American Review of Respiratory Diseases. 1978; 117: 773-781.

62. On collecting data on molecules for cataloguing, see De Chadarevian, Soraya. Following molecules: hemoglobin between the clinic and the laboratory. In: De Chadarevian, Soraya; Kamminga, Harmke, eds. Molecularizing biology and medicine. New practices and alliances. Amsterdam: Harwood; 1998, p. 171-201. On collecting data on molecules as a natural history practice, see Strasser, Bruno. Collecting and experimenting: the moral economies of biological research, 1960-1980s. In: History and epistemology of molecular biology and beyond: problems and perspectives. Berlin: Max Planck Institut für Wissenschaftsgeschichte; 2006. Preprint 310, p. 105-125. 
history to twentieth century patterns of industrializing drugs research. The early meaning of the term screening as a microbiological task included a set of artisanal steps, a method of manually collecting data about Actinomycetes, and an interaction with the factory system to produce new antibiotics.

\section{Acknowledgements}

I gratefully acknowledge the information provided by Roberto Gallego, Sagrario Mochales and Fernando Peláez regarding the early days of the screening program at CEPA and for granting me access to archival material and personal remembrances, as well as for their guidance in taking me through the publications of the group. I would like to thank Christoph Gradmann, Emilio Muñoz, Ana Romero, and the referees for Dynamis for their comments and suggestions to an earlier version of this article. 